\title{
Effect of long-term dietary protein intake on glucose metabolism in humans
}

\author{
T. Linn ${ }^{1}$, B.Santosa ${ }^{1}$, D. Grönemeyer ${ }^{2}$, S. Aygen ${ }^{3}$, N. Scholz ${ }^{4}$, M. Busch ${ }^{2}$, R. G. Bretzel ${ }^{4}$ \\ ${ }^{1}$ Clinical Research Unit, Medical Clinic 3, Giessen, Germany \\ ${ }^{2}$ Department of Radiology and MicroTherapy. University Witten/Herdecke, Germany \\ ${ }^{3}$ Institute of Clinical Chemistry, University Witten/Herdecke, Germany \\ ${ }^{4}$ Division of Diabetes and Metabolism, Medical Clinic 3, Giessen, Germany
}

\section{Abstract}

Aims/hypothesis. A meal rich in protein stimulates insulin secretion. Long-term effects of dietary protein on insulin release and glucose metabolism are, however, still not known. Our study focussed on the effect of different protein intake on pancreatic insulin secretion capacity, glycogen turnover and gluconeogenesis.

Methods. Subjects with constant (6 months) dietary protein of $1.87 \pm 0.26 \mathrm{~g} \cdot \mathrm{kg}^{-1} \cdot$ day $^{-1}(1.25-2.41)$ named high protein group and with $0.74 \pm 0.08$ $(0.57-0.80)$, normal protein group, were identified by a food questionnaire and were matched $(n=9)$ according to sex, age and calorie intake. They underwent an intravenous glucose tolerance test and a euglycaemic hyperinsulinaemic clamp with infusion of $\left[6,6-{ }^{2} \mathrm{H}_{2}\right]$-glucose combined with indirect calorimetry. To estimate net gluconeogenesis the usual diet was enriched by deuterated water or $\mathrm{U}-\left[{ }^{13} \mathrm{C}_{6}\right]$-glucose and breath and plasma were sampled.
Results. Glucose-stimulated insulin secretion was increased in the high protein group $(516 \pm 45 \mathrm{pmol} / \mathrm{l} \mathrm{vs}$ $305 \pm 32, p=0.012$ ) due to reduced glucose threshold of the endocrine beta cells $(4.2 \pm 0.5 \mathrm{mmol} / \mathrm{l}$ vs $4.9 \pm 0.3, p=0.031)$. Endogeneous glucose output was increased by $12 \%(p=0.009)$ at $40 \mathrm{pmol} / 1 \mathrm{plasma}$ insulin in the high protein group, but not at higher insulin concentration whereas overall glucose disposal was reduced. Fasting plasma glucagon was $34 \%$ increased in the high protein group $(p=0.038)$. Fractional gluconeogenesis was increased by $40 \%$ in subjects receiving a high protein diet as determined by both methods.

Conclusion/interpretation. High protein diet is accompanied by increased stimulation of glucagon and insulin within the endocrine pancreas, high glycogen turnover and stimulation of gluconeogenesis. [Diabetologia (2000) 43: 1257-1265]

Keywords Endogeneous insulin, hepatic glucose production, high protein diet, normal protein diet.
For different reasons interest in dietary protein intake has recently increased in diabetes research. Manipulation of protein ingestion has been used to slow down diabetic nephropathy [1]. Furthermore, epidemiological studies indicate that the quantity and qual-

Received: 21 February 2000 and in revised form: 15 June 2000

Corresponding author: T. Linn MD, PhD, Clinical Research Unit, Medical Clinic 3 and Policlinic, Justus-Liebig-University, Rodthohl 6, D-35392 Giessen, Germany

Abbreviations: HGO, Hepatic glucose output; HP, high protein; NP, normal protein; HMT, hexamethylenetetramine; APE, atom per cent excess. ity of protein ingestion affects the expression of Type I (insulin-dependent) diabetes mellitus [2, 3]. We have previously shown that a high protein diet accelerates the progression of the autoimmune loss of endogeneous insulin secretion in patients with Type I diabetes $[4,5]$. In general, high protein ingestion could be more detrimental in clinical situations with impaired glucose tolerance than is recognized; there is evidence that high protein intake promotes diabetes. Therefore, more knowledge is needed to decide in what way high dietary protein intake changes glucose metabolism in humans.

The protein supplied by a meal is a major stimulator of insulin secretion [6]. Dietary protein potential- 
Table 1. High protein group and low protein group of probands at entry

\begin{tabular}{llll}
\hline & High protein & Low protein & $p$ \\
\hline Number & 9 & 9 & \\
Age & $30.2 \pm 5.1$ & $29.7 \pm 6.3$ & NS \\
BMI $\left(\mathrm{kg} / \mathrm{m}^{2}\right)$ & $23.4 \pm 2.2$ & $22.7 \pm 2.0$ & NS \\
Sex $($ female/male $)$ & $7 / 6$ & $7 / 6$ & \\
\hline
\end{tabular}

ly determines, firstly, blood glucose concentrations by affecting insulin and counterregulatory hormone secretion [7] and, secondly, the postprandial availability of substrates for hepatic glucose synthesis in the portal vein [8]. Protein-rich meals increase the concentration of glucogenic substrates, particularly amino acids in addition to glucose and lactate. The addition of amino acids like glutamine alanine, and lactate to glucose has been shown to stimulate hepatic glycogen synthesis $[9,10]$. Other studies using amino acid infusions in vivo suggest that oxidative conversion of amino acids to glucose accounts for about one-half of the daily oxygen consumption of the liver [11]. Metabolic fluxes involved in the catabolism of dietary amino acids in humans are, however, most complex and not understood. Especially, there is little information available concerning the long-term effects of diet on intermediate metabolism.

The recommended daily allowance of dietary protein calculated by the World Health Organization (WHO) for healthy adults is $0.8 \mathrm{~g} \cdot \mathrm{kg}^{-1} \cdot \mathrm{day}^{-1}$ [12]. Although the WHO recommendation was made on the basis of scientific data on protein malnutrition, little has been published on the effect of increased longterm protein intake on health and life quality. Most people in the industrialized countries consume, however, more dietary protein than recommended by the WHO.

Our purpose was to examine the influence of longterm dietary protein intake, based on the dietary habits, on the insulin secretion process and liver glucose metabolism. We set out to find which are the mechanisms by which protein intake affects hepatic glucose metabolism in humans and whether a long-term high protein diet modifies pancreatic insulin secretory capacity. Using stable isotopes of the glucose molecule, but avoiding complicated isotopomer distributions [13], we estimated liver glucose metabolism by enrichment of liver glycogen with ingested ${ }^{13} \mathrm{C}$-labelled glucose for 1 week [5]. Gluconeogenesis was estimated by non-invasive diet-adapted procedures using stable isotopes of glucose and deuterium.

\section{Materials and methods}

Subjects and study design. Volunteers were asked to record their food items for 7 days by a standardized procedure [14]. Subjects with $0.8 \mathrm{~g}$ protein per $\mathrm{kg}$ or less a day and those with more than $0.8 \mathrm{~g} \cdot \mathrm{kg}^{-1} \cdot \mathrm{day}^{-1}$ were identified and asked to participate in the study. To separate the effects of energy and protein intake subjects with $0.8 \mathrm{~g} / \mathrm{kg}$ or less and those with more than $0.8 \mathrm{~g} / \mathrm{kg}$ daily dietary protein were matched according to sex, age and calorie intake. These subgroups were named high protein $(=\mathrm{HP})$ and normal protein $(=\mathrm{NP})$ group with mean protein intake of $1.87 \pm 0.26$ (range $1.25-2.41$ ) and $0.74 \pm 0.08$ (range $0.57-0.80) \mathrm{g} \cdot \mathrm{kg}^{-1} \cdot \mathrm{day}^{-1}$, respectively (Table 1 ). Subjects were asked to adhere to their usual diet for 6 months and they gave their written consent to the study protocol. After six months all participants repeated the food record. No proband had changed his dietary habits, weight or nitrogen excretion. Thereafter, they underwent the following metabolic tests starting at least 5 days apart; an intravenous glucose tolerance test over $180 \mathrm{~min}$, a euglycaemic hyperinsulinaemic clamp with infusion of $\left[6,6-{ }^{2} \mathrm{H}\right]$-glucose and combined indirect calorimetry, ${ }^{13} \mathrm{C}$-glucose enrichment of usual diet, and drinking of $0.5 \%{ }^{2} \mathrm{H}_{2} \mathrm{O}$ with concomitant sampling of breath, blood and urine. The study was approved by the local ethics committee.

Food questionnaire. Dietary assessments were carried out under the review of one of the authors using a 7-day food record system [14] at entry and after 6 months. The records contained questions for each food item, e.g. time of day, amount of serving and frequency of eating. When the probands had completed their records, they were reviewed with the subject for completeness of descriptions of foods and amounts. Food models and measuring utensils were applied. Probing questions were used to identify food items, which might have been overlooked. Within-record variability ranged from 0.51 to 0.72 for various food components. The ratios of within-person to between-person variance in dietary estimates was 0.91 for energy, 0.84 for carbohydrates, 1.22 for fat and 1.38 for protein. The food diary was validated before on a large scale (National Consumption Survey) including people with diabetes mellitus [15]. To validate food recording protein intake was also calculated from the urinary urea nitrogen and an estimated non-urea nitrogen excretion of $29 \mathrm{mg} \mathrm{N} \cdot \mathrm{kg}^{-1} \cdot$ day $^{-1}$ using Maroni's equation $[16,17]$.

Intravenous glucose tolerance test. After an overnight fast baseline blood samples were drawn at 10 and 5 min before the injection of glucose ( $0 \mathrm{~min})$. In the contralateral vein, a $1.4 \mathrm{~mm}$ 17 -gauge cannula was inserted for the injection of $0.3 \mathrm{~g} \cdot \mathrm{kg}^{-1}$ $50 \%$ glucose for $60 \mathrm{~s}$. Venous blood for short-term insulin response to glucose was sampled at 2, 3, 4, 5, 6, 8, $10 \mathrm{~min}$. More samples $(n=22)$ were obtained over a total of $180 \mathrm{~min}$ for measurements of plasma glucose concentration and immunoreactive insulin.

Euglycaemic clamp. The test was started after a 12-h overnight fast and lasted $6 \mathrm{~h}$. A polyethylene catheter was inserted into an antecubital vein for the infusion of test substances. A second catheter was inserted retrogradely into a wrist vein for blood sampling. The hand was placed on a heating pad to ensure arterialization of venous blood. An intravenous priming dose $(400 \mathrm{mg})$ of $\left[6,6-{ }^{2} \mathrm{H}_{2}\right]$-glucose was followed by continuous infusion at $100 \mu \mathrm{g} \cdot \mathrm{kg}^{-1} \cdot \mathrm{min}^{-1}$. After $2 \mathrm{~h}$ of isotopic equilibration blood samples were drawn at 10 min intervals from 120 to $150 \mathrm{~min}$.

Thereafter a 120-min hyperinsulinaemic clamp was started with a prime-continuous infusion of crystalline human insulin (Insuman Rapid, Hoechst-Marion-Roussell, Hoechst Germany) at the rate of $0.3 \mathrm{mU} \cdot \mathrm{kg}^{-1} \cdot \mathrm{min}^{-1}$ to achieve an increment in plasma insulin concentration of approximately $100 \mathrm{pmol} / \mathrm{l}$. The plasma glucose concentration was maintained at $4.5-5 \mathrm{mmol} / \mathrm{l}$ by measuring it at $5-\mathrm{min}$ intervals and by periodic 
adjustment of a $20 \%$ glucose infusion. The variable glucose infusion was labelled with $5 \%\left[6,6-{ }^{2} \mathrm{H}_{2}\right]$-glucose. Throughout the insulin clamp blood samples were drawn at 20 min intervals to measure total glucose, glucose isotopes and insulin concentrations. At $240 \mathrm{~min}$ the rate of insulin infusion was increased to $1 \mathrm{mU} \cdot \mathrm{kg}^{-1} \cdot \mathrm{min}^{-1}$ to achieve and maintain an increment in plasma insulin concentration of approximately $420 \mathrm{pmol} / \mathrm{l}$ for another $2 \mathrm{~h}$.

Indirect calorimetry. A calorimeter (Deltatrac, Flensburg, Germany) was used to measure energy consumption in the basal state and during the euglycaemic clamp. A transparent plastic ventilator hood was placed over the head of the subject and made airtight around the neck. Carbon dioxide and oxygen content of expired air was continuously measured. On three successive days 24-h urine was collected to measure urea nitrogen. The rates of glucose and lipid oxidation were calculated from the non-protein respiratory quotient assuming protein oxidation to be constant during the 8.5-h study. Non-oxidative glucose disposal was calculated subtracting the glucose oxidation rate from the rate of glucose disappearance. Protein oxidation was estimated from urinary nitrogen excretion.

Hepatic ${ }^{13} \mathrm{C}$-glucose and body water deuterium enrichment. During 5 days subjects ingested $2.4 \mathrm{~g} \mathrm{U}-\left[{ }^{13} \mathrm{C}\right]$-glucose per day added to their main meals. At 3 days before and during the 5-day period respiratory gas exchanges, urinary nitrogen and breath ${ }^{13} \mathrm{CO}_{2}$ were measured every morning in the postabsorptive state under resting conditions after an overnight fast. A plasma sample was taken for the measurement of plasma ${ }^{13} \mathrm{C}$ enrichment. An aliquot of the urine collected at 24-h intervals was analysed for urea nitrogen.

After 3 weeks ${ }^{13} \mathrm{C}$ abundance in breath and blood had returned to background values. At the end of this period probands ate a meal at 2000 hours. They then fasted for $22 \mathrm{~h}$ except for water ingestion. At $5 \mathrm{~h}$ after beginning the fast an i.v. infusion of $\left[6,6-{ }^{2} \mathrm{H}\right]$-glucose was started and they drank water enriched $0.5 \%$ with ${ }^{2} \mathrm{H}_{2} \mathrm{O}$ beginning with a loading dose of $3.5 \mathrm{ml}^{2} \mathrm{H}_{2} \mathrm{O}$ (99.9\% 2H; Isocom, Landshut, Germany). Body water was calculated to be $50 \%$ of body weight in women and $60 \%$ in men. Peripheral vein blood was drawn every $2 \mathrm{~h}$ from the 10 th to $22 \mathrm{nd} h$ of the fast.

\section{Materials and analyses}

Insulin was measured by radioimmunoassay with the reagents of Pharmacia, Uppsala, Sweden as described [4]. Glucose was analysed by a Beckman Glucose Analyser (Beckman, Heidelberg, Germany). We obtained D-[6,6- $\left.{ }^{2} \mathrm{H}\right]$-glucose (98\% mole excess), and U- $\left[{ }^{13} \mathrm{C}\right]$-glucose (99\% mole excess) from Cambridge Isotope Laboratories, Andover, Mass., USA. Chemical and isotopic purity were confirmed by gas chromatography selected ion monitoring mass spectrometry analysis. We dissolved $\left[6,6-{ }^{2} \mathrm{H}\right]$-glucose in sterile isotonic saline and passed it through a $0.22-\mu \mathrm{m}$ Millipore filtre before infusion. The preparation was pyrogen free.

Gas chromatography-mass spectrometry analysis of breath and plasma samples from oral $\left[U^{13} \mathrm{C}\right]$-glucose enrichment. Breath samples were collected in evacuated airtight glass tubes. Breath ${ }^{13} \mathrm{CO}_{2}$ isotope enrichment was measured by isotope ratio mass spectrometer (Optima $\mu \mathrm{Gas}$; Micromass UK, Altrincham, UK).

For measurement of $\left[6,6-{ }^{2} \mathrm{H}\right]$-glucose and U-[ $\left.{ }^{13} \mathrm{C}\right]$-glucose plasma samples were deproteinized by mixing with $1 \mathrm{ml}$ etha- nol. After centrifugation the supernatant was evaporated to dryness in a stream of helium and an aldonitrile pentacetate derivative of glucose was prepared [18].

An aliquot of the solution $(1 \mu \mathrm{l})$ was injected into a gas chromatography-mass spectrometer (Philipps 405) system equipped with a 60-m fused silica capillary column OV-1 (Philipps, Potomac, USA). The peak abundance of ions $\mathrm{m} / \mathrm{z} 458$ for $\left[{ }^{13} \mathrm{C}\right]$-glucose and $\mathrm{m} / \mathrm{z} 454(\mathrm{~m}+2$ at $\mathrm{C}-6)$ for $\left[6,6-{ }^{2} \mathrm{H}\right]$-glucose was monitored for calculating the plasma enrichment of the labelled glucose. The precision of glucose measurement in plasma by isotope dilution showed coefficients of variation of 0.86 to $0.99 \%$.

Analysis of deuterium enrichment. ${ }^{2} \mathrm{H}$-hydrogens bound to carbon 2 and 5 of blood glucose, and in urinary water were determined by Ibona Laboratories, Gruenberg, Germany as described previously [9]. The supernatant, obtained after deproteinizing a blood sample by $\mathrm{ZnSO}_{4}-\mathrm{Ba}(\mathrm{OH})_{2}$ addition, was deionized by passage through cation and anion exchange resins. Glucose in the effluent was isolated by HPLC. In principle, C-2 or C-5 enrichment was assayed in hexamethylenetetramine (HMT, mass 141), formed from formaldehyde produced by periodate oxidation of glucose. To prepare HMT containing the hydrogens bound to C-5, C- 6 was removed by conversion of glucose to xylose. To prepare HMT containing hydrogens bound to $\mathrm{C}-2$, C-1 of glucose was decarboxylated by conversion of glucose to ribulose-5-P. The ribulose-5-P was reduced to a mixture of the polyol phosphates, ribitol-5-P and arabitol-5-P.

For periodate oxidation $2 \mathrm{mg}$ of the dry substance was dissolved in sodium metaperiodate and $1 \mathrm{~N} \mathrm{HCl}$ and $1.2 \mathrm{~mol} / \mathrm{l} \mathrm{so-}$ dium arsenite were added. The solution was distilled and concentrated $\mathrm{NH}_{4} \mathrm{OH}$ was added. After evaporation the residue was taken up in methylene choride. The deuterium enrichment of HMT (mass 141) was measured on a gas chromatographmass spectrometer [glass column $(3.2 \mathrm{~mm}, 1.8 \mathrm{~m})$ packed with $3 \%$ OV-17, 100-120 mesh, oven temperature $120^{\circ} \mathrm{C}$, carrier gas helium at flow rate $21 \mathrm{ml} / \mathrm{min}$, retention time for HMT $5 \mathrm{~min}]$.

The ${ }^{2} \mathrm{H}$-enrichment of the diluted urine sample was measured following zinc reduction at $490{ }^{\circ} \mathrm{C}$ to produce deuterium gas, as deviations of ${ }^{2} \mathrm{H} / \mathrm{H}$ ratio in per mil $\left(\delta^{2} \mathrm{H} \%\right.$ parts per thousand) from that of the reference water $\left({ }^{2} \mathrm{H} / \mathrm{H}=0.000178\right)$ on an isotope ratio mass spectrometer.

\section{Calculations and statistical analysis}

Intravenous glucose tolerance test. Short-term insulin response to intravenous glucose was measured as the mean insulin concentration above basal from 2-10 min after the glucose injection. A model for posthepatic delivery of insulin into the circulation was established estimating two additional variables: $\mathrm{n}\left[\mathrm{min}^{-1}\right]=$ first-order degradation constant of the insulin bolus, and $\mathrm{h}[\mathrm{mmol} / \mathrm{l}]=$ glucose threshold for the release of insulin. The insulin and glucose data of the intravenous glucose tolerance test were further analysed using the minimal model of glucose kinetics to derive indexes of insulin sensitivity $\left(\mathrm{S}_{\mathrm{I}}\right)$ and glucose effectiveness $\left(\mathrm{S}_{\mathrm{G}}\right)$ at basal insulin concentration.

Euglycaemic hyperinsulinaemic clamp. Endogenous glucose output (EGO) was calculated from enrichment as atom per cent excess (APE) of $\left[6,6-{ }^{2} \mathrm{H}_{2}\right]$-glucose in the plasma. Glucose disposal $\left(R_{d}\right)$ was calculated from the average glucose infusion rate $\left(\mu \mathrm{mol} \cdot \mathrm{kg}^{-1} \cdot \mathrm{min}^{-1}\right)$ substracted by EGO. Under steady- 
Table 2. Mean dietary intake of probands on HP or NP isocaloric diet

\begin{tabular}{lccl}
\hline & High protein & Normal protein & $p$ \\
\hline Protein $\left(\mathrm{g} \cdot \mathrm{kg}^{-1} \cdot \mathrm{day}^{-1}\right)$ & $1.81 \pm 0.26$ & $0.71 \pm 0.08$ & 0.0013 \\
Fat $\left(\mathrm{g} \cdot \mathrm{kg}^{-1} \cdot \mathrm{day}^{-1}\right)$ & $0.95 \pm 0.11$ & $0.86 \pm 0.12$ & $\mathrm{NS}$ \\
Carbohydrate $\left(\mathrm{g} \cdot \mathrm{kg}^{-1} \cdot \mathrm{day}^{-1}\right)$ & $2.31 \pm 0.67$ & $2.93 \pm 0.68$ & 0.035 \\
Fiber $\left(\mathrm{g} \cdot \mathrm{kg}^{-1} \cdot \mathrm{day}^{-1}\right)$ & $0.11 \pm 0.10$ & $0.18 \pm 0.03$ & 0.021 \\
Energy $\left(\mathrm{kJ} \cdot \mathrm{kg}^{-1} \cdot \mathrm{day}^{-1}\right)$ & $127.5 \pm 23.9$ & $119.8 \pm 18$ & $\mathrm{NS}$ \\
\hline
\end{tabular}

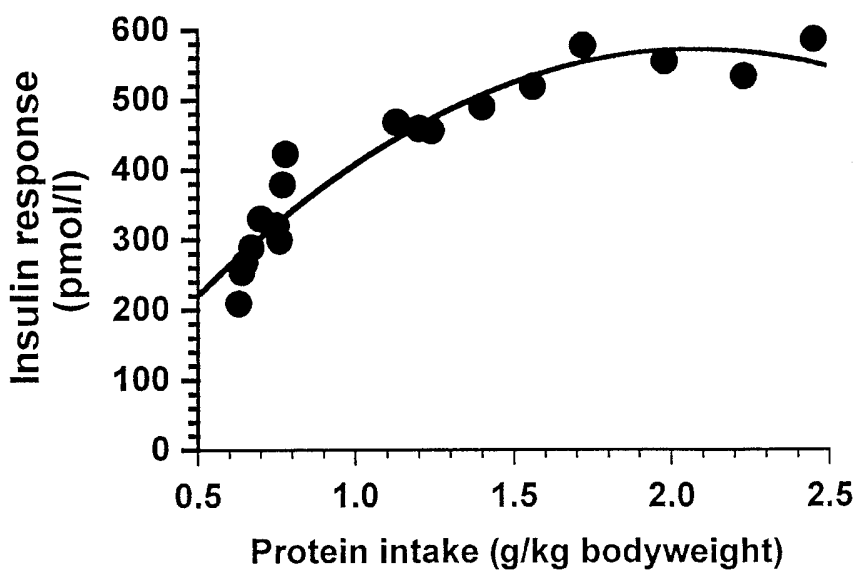

Fig. 1. Correlation between daily protein intake (in $\mathrm{g} / \mathrm{kg}$ ) and acute insulin response to glucose as an estimate of insulin secretion capacity; $r^{2}=0.97, p<0.001$

state conditions the rate of glucose appearance $\left(R_{a}\right)$ is identical with $R_{d}$, and $R_{d}=A P E_{i} / A P E_{p} \times F$, where $A P E_{i}=A P E$ of the infused solution, $\mathrm{APE}_{\mathrm{p}}=\mathrm{APE}$ of plasma, and $\mathrm{F}=$ infusion rate of labelled glucose. During the euglycaemic clamp, $R_{d}$ and EGO were calculated by means of Steele's [20] non-steady state equations as modified by De Bodo [21].

Ingested isotopes $\left({ }^{13} \mathrm{C}\right.$-glucose and $\left.{ }^{2} \mathrm{H}_{2} \mathrm{O}\right)$. Because indirect calorimetry estimates net substrate oxidation rates, glucose oxidation measured in the postabsorptive state is exclusively accounted for by oxidation of endogeneous glycogen. Net carbohydrate oxidation corresponds to oxidation by peripheral tissues of glucose issued from glycogen hydrolysis. Assuming that ${ }^{13} \mathrm{C}$-glycogen enrichment can be calculated from $\mathrm{CO}_{2}$ enrichment and $\mathrm{VCO}_{2}$, the following equation ahs been proposed previously: ${ }^{13} \mathrm{C}$ glycogen enrichment $=$ breath ${ }^{13} \mathrm{CO}_{2} \times \mathrm{VCO}_{2} /$ $\mathrm{VCO}_{2(\mathrm{CHO})} \times 0.8$, where $\mathrm{VCO}_{2(\mathrm{CHO})}$ is the fraction of total $\mathrm{VCO}_{2}$ used for oxidation of carbohydrate and 0.8 is the recovery factor for ${ }^{13} \mathrm{CO}_{2}$ in breath [22]. Fractional gluconeogenesis (expressed in \%) was calculated as ${ }^{13} \mathrm{C}$-glycogen enrichment minus plasma U- $\left[{ }^{13} \mathrm{C}\right]$-glucose divided by ${ }^{13} \mathrm{C}$-glycogen enrichment.

Gluconeogenesis was also estimated by deuterium enriched water. The percentage contribution of gluconeogenesis to glucose production was set equal to 100 times the excess enrichment of the hydrogen bound to C-5 compared with C-2 of the glucose (C-5:C-2 ratio) or compared with deuterium in urinary water. The rate of glycogenolysis was calculated by substracting gluconeogenesis from glucose production.

Expression of the results and statistical treatment values are means \pm SEM. Baseline characteristics, $R_{d}$ and insulin secretion were analysed by Student's $t$ test for unpaired data. One way analysis of variance (ANOVA) was used to evaluate the differences of substrate oxidation rates, hepatic glucose output and glucagon concentrations (groups: different insulin concentrations). When the analysis of variance resulted in a significant $F$ value, the difference between means was identified by the Newman-Keul post-hoc test. Linear correlation was calculated using Pearson's correlation coefficient. The tests were done with the Statistical Package for the Social Sciences (SPSS) software system (SPSS, Heidelberg, Germany).

\section{Results}

Diet. Protein intake in both groups assessed by 7-day food records (Table 2) was similar to that estimated from urinary urea excretion and it was stable for months on an individual basis (coefficient of variation $<7 \%$ ). Carbohydrate intake was significantly lower in the HP group. Mean urinary urea nitrogen excretion was $3.0 \pm 0.9 \mathrm{mmol} \cdot \mathrm{kg}^{-1} \cdot \mathrm{day}^{-1}$ in the $\mathrm{HP}$ group and $1.6 \pm 0.8 \mathrm{mmol} \cdot \mathrm{kg}^{-1} \cdot \mathrm{day}^{-1}$ in the NP group $(p<0.02)$. Energy production calculated from indirect calorimetry correlated significantly with the estimates obtained from the food questionnaire $\left(r^{2}=0.83, p<0.0001\right)$.

Glucose stimulated insulin release. Short-term insulin response to glucose correlated to protein intake by a second grade function (Fig.1). Protein consumption of all probands had a range of 0.6 to $2.2 \mathrm{~g} \cdot \mathrm{kg}^{-1} \cdot$ day $^{-1}$ and it was associated with stimulated insulin ranging from 220 to $540 \mathrm{pmol} / \mathrm{l}$. The frequently sampled intravenous glucose tolerance test showed that the mean glucose-stimulated insulin response in the HP group was significantly $(p=0.012)$ increased compared with the NP cohort (Table 3). This effect was due to increased glucose sensitivity of the beta cell, because glucose threshold (h) for insulin secretion was $15 \%$ lower $(p=0.031)$ in subjects with high protein consumption (Table 3 ). The insulin degradation rate did not differ between the two dietary groups.

Glucose turnover. At a low plasma insulin concentration $(\sim 40 \mathrm{pmol} / \mathrm{l})$ endogenous glucose output was $12 \%$ higher in the HP group $(12.2 \pm 0.51$ for HP and $10.9 \pm 0.54 \mu \mathrm{mol} \cdot \mathrm{kg}^{-1} \cdot \mathrm{min}^{-1}$ for the NP group, $p<0.01$, Fig. 2). During the hyperinsulinaemic clamp EGO was equally suppressed in both dietary groups. Overall glucose disposal at $100 \mathrm{pmol} / \mathrm{l}$ was slightly, but significantly, lower in the HP group $(4.3 \pm$ $2.2 \mathrm{mg} \cdot \mathrm{kg}^{-1} \cdot \mathrm{min}^{-1} \mathrm{HP}$ vs $\left.4.7 \pm 2.6 \mathrm{NP}, p<0.05\right)$, 
Table 3. Results of the intravenous glucose tolerance test (0-180 min) analysed by insulin kinetics and insulin sensitivity model

\begin{tabular}{lccl}
\hline & High protein & Normal protein & $p$ \\
\hline Insulin response $(\mathrm{pmol} / \mathrm{l})$ & $516 \pm 45$ & $305 \pm 32$ & $0.012^{\mathrm{a}}$ \\
$\mathrm{n}\left(\mathrm{min}^{-1}\right)$ & $0.21 \pm 0.07$ & $0.18 \pm 0.05$ & 0.32 \\
$\mathrm{~h}\left(\mathrm{mmol}^{-1}\right)$ & $4.2 \pm 0.5$ & $4.9 \pm 0.3$ & $0.031^{\mathrm{a}}$ \\
$\mathrm{SI}\left(10^{-5} \cdot \mathrm{min}^{-1} \cdot \mathrm{pmol} / \mathrm{l}^{-1}\right)$ & $5.1 \pm 1.2$ & $7.8 \pm 1.9$ & $0.044^{\mathrm{a}}$ \\
$\mathrm{Sg}\left(10^{-2} \cdot \mathrm{min}^{-1}\right)$ & $1.21 \pm 0.1$ & $1.69 \pm 0.2$ & $0.037^{\mathrm{a}}$ \\
$K$ value & $2.4 \pm 0.6$ & $2.1 \pm 0.5$ & 0.53 \\
\hline
\end{tabular}

$K$, glucose assimilation coefficient; $\mathrm{n}$, first-order degradation rate of insulin bolus released in response to i.v. glucose; h, glucose threshold for insulin secretion; SI, insulin sensitivity index; $\mathrm{Sg}$, glucose effectiveness. Data are given as means \pm SEM

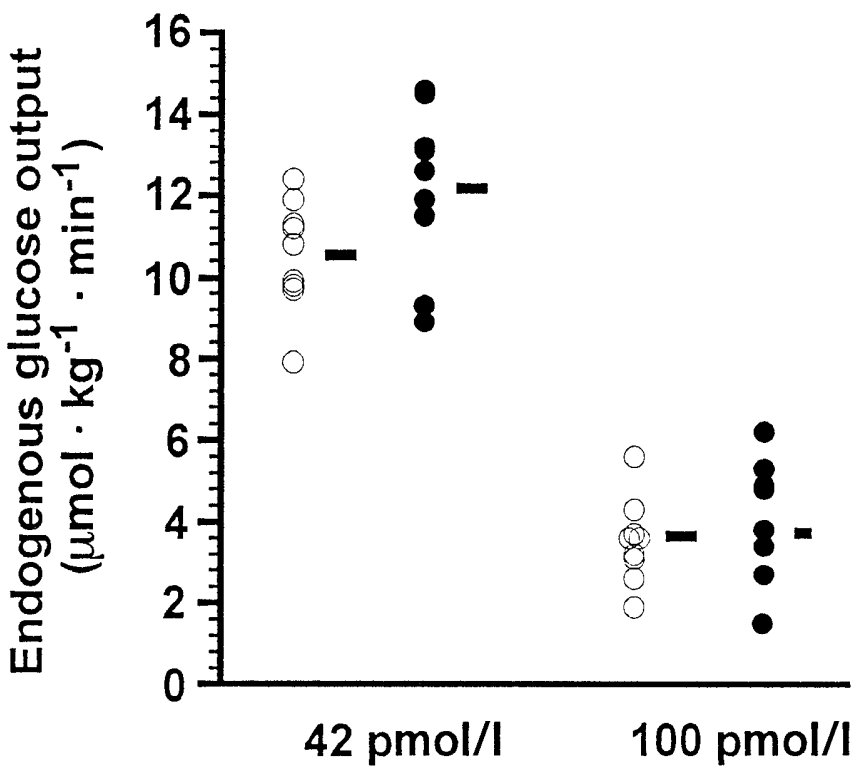

Fig. 2. Endogenous glucose output at different insulin concentrations in NP $(O)$ and HP $(\mathbf{O})$ probands measured by twostepped euglycaemic clamp

which is consistent with the reduction of insulin sensitivity $\mathrm{S}_{\mathrm{I}}$ in the minimal model analysis (Table 3). Plasma glucagon in the presence of low insulin concentrations was increased in the HP group, suppression of glucagon secretion by higher insulin concentrations was not different (Fig. 3). Glucose effectiveness $S_{G}$, i.e. the ability of glucose to stimulate its absorption by peripheral tissues, calculated from the minimal model of glucose kinetics was decreased by $26 \%$ in the HP cohort (Table 3).

Substrate oxidation. In the basal state, protein oxidation was significantly higher in the HP group as estimated from urea nitrogen excretion $(1.12 \pm 0.52 \mathrm{vs}$ $0.82 \pm 0.5 \mathrm{mg}$ protein $\left.\cdot \mathrm{kg}^{-1} \cdot \mathrm{min}^{-1}, p<0.05\right)$. Glucose oxidation was reduced by $23 \%$ in the HP group $\left(5.6 \pm 0.90\right.$ vs $\left.7.4 \pm 0.83 \mathrm{mg} \cdot \mathrm{kg}^{-1} \cdot \mathrm{min}^{-1}, \quad p<0.05\right)$ and with respect to lipid oxidation there was no significant difference between the two groups (Table 4). For this, glucose oxidation was assumed to be constant for a given and maintained concentration of insulin.

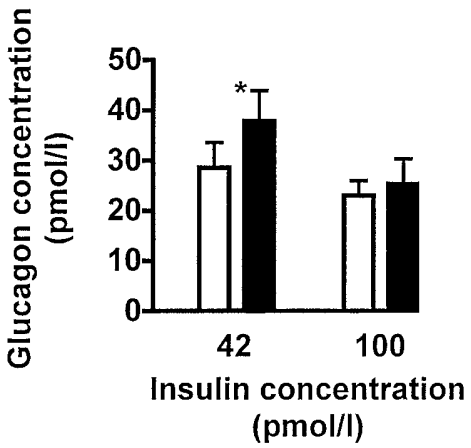

Fig. 3. Glucagon concentrations during two-stepped euglycaemic hyperinsulinaemic clamp with high protein $(\mathbf{O})$ or normal protein $(\bigcirc)$ dietary intake. $* p<0.05$

Hepatic glycogen accumulation. Plasma ${ }^{13} \mathrm{C}$-glucose enrichment increased rapidly when the ${ }^{13} \mathrm{C}$-enriched diet was started and reached a plateau after 4 days (Fig.4). At the plateau plasma ${ }^{13} \mathrm{C}$-glucose enrichment represented about $50 \%$ of the ${ }^{13} \mathrm{C}$-carbohydrate enrichment of the diet for both groups. Resting, postabsorptive breath ${ }^{13} \mathrm{CO}_{2}$ also increased progressively when the ${ }^{13} \mathrm{C}$-enriched diet was started reaching a plateau after 5 days (Fig. 4). The ${ }^{13} \mathrm{C}$-enrichment of hepatic glycogen, i.e. of glucose oxidized at rest, assumed to be essentially of hepatic origin, was $104 \pm 8 \%$ of the ${ }^{13} \mathrm{C}$-enrichment of dietary carbohydrates.

The fraction of glucose produced by gluconeogenesis calculated from ${ }^{2} \mathrm{H}$-enrichment after $14 \mathrm{~h}$ of fasting was $45.2 \pm 5.4 \%$ in the NP group and $63.1 \pm 5.6 \%$ in the HP group $(p<0.05$, Fig. 5$)$. In subjects from the NP group plasma U- $\left[{ }^{13} \mathrm{C}\right]$-enrichment represented $51.5 \pm 2.9 \%$ of the enrichment of hepatic glycogen as calculated from ${ }^{13} \mathrm{C}$-enrichment of breath samples. This corresponded to a fractional gluconeogenesis of $48.7 \pm 6.2 \%$. By contrast, net gluconeogenesis in the HP group was $68.7 \pm 3.5 \%(p<0.02)$ fitting well to the data from the deuterated water technique. The time required to renew $50 \%$ of hepatic glycogen as estimated by plasma $\mathrm{U}-\left[{ }^{13} \mathrm{C}\right]$-enrichment was an estimated $19.2 \pm 3.8 \mathrm{~h}$ in the NP group and $16.2 \pm 3.1 \mathrm{~h}$ in the HP group $(p<0.02)$; i.e. glycogen turnover was increased in the HP group. Accordingly, glycogenolysis calculated from deuterated water 
Table 4. Substrate oxidation rates $\left(\mathrm{mg} \cdot \mathrm{kg}^{-1} \cdot \mathrm{min}^{-1}\right)$ in the fasting state $(\approx 40 \mathrm{pmol} / \mathrm{l}$ "basal" insulin) and during the last hour of the euglycemic hyperinsulinaemic $(\approx 420 \mathrm{pmol} / \mathrm{l}$ "high" insulin) clamp

\begin{tabular}{lll}
\hline & High protein & Normal protein \\
\hline Glucose oxidation & & \\
$\quad$ Basal & $5.6 \pm 0.90$ & $7.4 \pm 0.83^{\mathrm{a}}$ \\
$\quad$ High & $17.7 \pm 1.9$ & $18.2 \pm 2.6$ \\
Protein oxidation & & \\
$\quad$ Basal & $1.12 \pm 0.52$ & $0.82 \pm 0.5^{\mathrm{a}}$ \\
$\quad$ High & n.d. & n.d. \\
Lipid oxidation & & \\
$\quad$ Basal & $0.83 \pm 0.08$ & $0.73 \pm 0.15$ \\
High & n.d. & n.d. \\
\hline
\end{tabular}

${ }^{\mathrm{a}} p<0.05$ HP vs NP. n.d. $=$ not determined

loading was higher in the HP group at 14-h fast $\left(6.71 \pm 0.31 \quad\right.$ vs $\quad 5.12 \pm 0.24 \mu \mathrm{mol} \cdot \mathrm{kg}^{-1} \cdot \mathrm{min}^{-1}$, $p<0.05) \mu \mathrm{mol} \mathrm{kg}-1 \mathrm{~min}^{-1}$.

\section{Discussion}

The secretion of insulin into the blood stream is increased by the consumption of dietary protein during a meal. We have found that plasma insulin concentrations are not only increased by a single protein-rich meal, but also by long-term high protein intake. Stimulation in the early phase of insulin release with an intravenous glucose bolus gives the possibility to estimate the maximum insulin secretory capacity of beta cells in non-diabetic humans [23, 24, 25]. Deconvolution of insulin secretion kinetics showed that protein intake augmented the sensitivity of the endocrine pancreas to glucose by $15 \%$. Improvement of betacell glucose sensitivity was recently described for the enterohormone glucagon-like peptide (7-36) [26, 27, $28,29]$, which is stimulated by dietary protein and fat. Dietary protein is associated with stimulation of growth hormone and insulin-like growth factor [30, $31,32]$, and it is known that in states of increased metabolic demand, nutrient availability, and growth hormone production (as for instance pregnancy) islet tissue expands $[33,34]$. These lines of evidence imply that a high protein diet increases the capacity for insulin secretion.

A mixed meal stimulates glucagon secretion [35], exerts a protein-anabolic effect [36] and temporarily enhances endogeneous glucose production 1-4 h after the meal by $50 \%$ [37]. Conversely, inhibition of glucagon secretion considerably reduced glycogen turnover under conditions of hyperglycaemia and basal insulinaemia [38]. Our data show that a highprotein diet did not only modify glucose metabolism for the duration of a single meal as previously described [39, 40, 41], but had long-term effects on the regulation of substrate metabolism. These effects

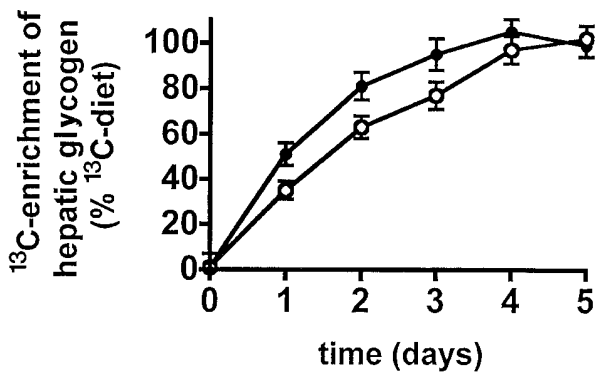

B

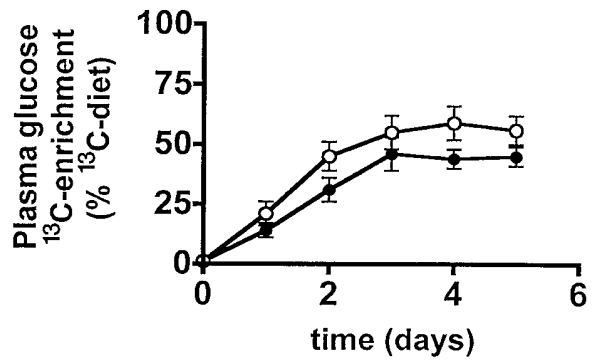

Fig. 4 A,B. ${ }^{13} \mathrm{C}$-enrichment of hepatic glycogen oxidized at rest (calculated from breath ${ }^{13} \mathrm{CO}_{2}$ and respiratory gas exchanges, A) and ${ }^{13} \mathrm{C}$ plasma glucose (B) during 5 consecutive days after initiation of a diet labelled with $\mathrm{U}\left[{ }^{13} \mathrm{C}\right]$ glucose. Results (means \pm SD) are expressed as per cent enrichment of oral $\mathrm{U}\left[{ }^{13} \mathrm{C}\right]$ glucose $(0.01 \mathrm{APE})$ with high protein (HP) group and $\bigcirc$ normal protein (NP) group

persisted for a minimum time of $8-10 \mathrm{~h}$ during the overnight fast. The ${ }^{13} \mathrm{C}$-glucose turnover in plasma and air showed that dietary protein probably modified glucose metabolism over several weeks. Substrates delivered by subsequent protein-rich meals reduced overall glucose disposal in low-insulin and high-insulin states. Based on our calorimetric data glucose oxidation was reduced by high-protein intake. In addition, hepatic glucose production was increased in close association with plasma glucagon which was still stimulated hours after the last protein rich meal. All of these mechanisms resulted in a state of insulin resistance and glucose intolerance.

Our data suggest that amino acids contributed to gluconeogenesis and total hepatic glucose output in the postabsorptive state, as has been suggested to occur in the fed state [6]. Either as a result of the rising glucagon concentrations or induced by the increased emergence of gluconeogenic amino acids, high-protein intake stimulated fractional hepatic gluconeogenesis activating glycogen turnover and subsequently increasing hepatic glucose output in the presence of low plasma insulin concentrations. Therefore, people consuming a high-protein diet and activated gluconeogenesis and glycogenolysis are shown to have an increased hepatic glucose production, however a reduced overall glucose disposal.

Conversely, consumption of a protein-controlled diet would reduce the protein component of hepatic glucose production, decreasing gluconeogenesis and basal insulin secretion of normal people. This sugges- 


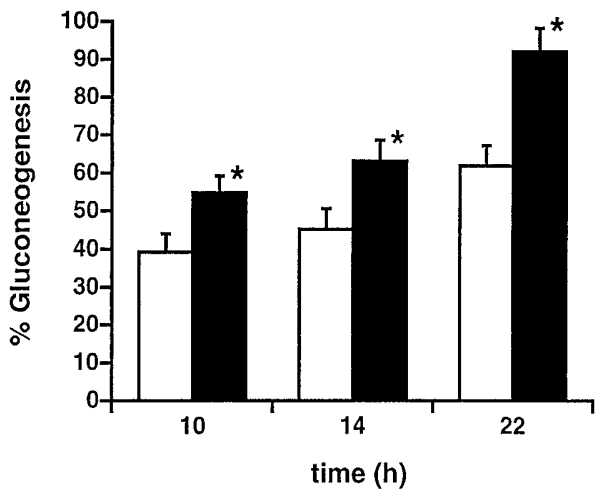

Fig. 5. Estimates of gluconeogenesis during fasting over $22 \mathrm{~h}$. $\%$ gluconeogenesis was calculated from comparison of deuterium enrichment at $\mathrm{C} 5$ with that at $\mathrm{C} 2$ of glucose. Data are presented as means \pm SD for the high protein (HP) group (black bars) and the normal protein (NP) group (white bars). Differences between HP and NP were significant $(p<0.05)$ at all time points

tion is consistent with our results on fractional gluconeogenesis. Increased hepatic glucose production due to high-protein intake results from increased gluconeogenesis.

Under conditions in which hepatic glycogen stores are high, a decrease in the glycogenolytic rate and an increase in the rate of glucose cycling within the liver seem to be the explanation for the decrease in hepatic glucose output seen in response to hyperglycaemia [42]. Promotion of hepatic glycogen cycling could be the principal mechanism by which insulin inhibits net hepatic glycogenolysis and endogenous glucose production in humans under euglycaemic conditions.

The NP group ingested more carbohydrates (43cal\%) than the HP group (31cal\%), which raises the question, whether the observed higher insulin sensitivity in the NP group is caused by a higher amount of carbohydrates. We examined patients $(n=6)$ of the NP group with $60 \mathrm{cal} \%$ carbohydrate and low fat intake and found neither hepatic glucose production nor overall insulin sensitivity differed from the NP group with 43 cal\% carbohydrates (data not shown).

Although an effect of infused amino acids to decrease insulin sensitivity during a glucose clamp is reported by two studies $[43,44]$ others could not confirm this $[6,10]$ so that a clear definition is lacking.

We used two new non-invasive diet-based methods to calculate long-term effects on gluconeogenesis under different assumptions. Estimation of the ${ }^{13} \mathrm{C}$-glucose technique theoretically assumes that all the plasma glucose pool equilibrates with breath and the hepatic pool. Because this assumption has not been validated before, we compared the calculations of the ${ }^{13} \mathrm{C}$-glucose technique with the deuterium method. The major assumption made by this procedure is a complete exchange between deuterium in body water and the two hydrogens bound to the carbon 3 of phosphoenolpyruvate. Hence, all the phosphoenolpyruvate formed from pyruvate, alanine, and lactate should then bear label from the protons of water and provide a measure of gluconeogenesis from those gluconeogenic substrates. Glycerol's contribution to gluconeogenesis is not included in these estimates. Studies with $\left[3-{ }^{3} \mathrm{H}, 3-{ }^{14} \mathrm{C}\right]$-lactate have shown that equilibrium of the hydrogen bound to carbon 6 with that in body water was $80-90 \%$ complete, so that gluconeogenesis is underestimated by $10-20 \%$ [13]. This corresponds to our results and implies that the $13 \mathrm{C}$ glucose method is valid under the conditions of the experimental design of our study.

Both procedures avoid the theoretical problems associated with giving labelled precursors [45, 46] and reasonably correlate with data from recent nuclear magnetic resonance studies [47].

The drawbacks of those non-invasive methods are that they cannot be used to arrive at a decision on the glucose metabolic pathway. We cannot rule out recyclings between the direct and the indirect pathway. Glucose cycling is not recognized by the methods we used. With the ${ }^{13} \mathrm{C}$-glucose technique we only studied net glucose fluxes between the direct and indirect glucose metabolism pathways. Glucose cycling is especially increased in pathological states of glucose metabolism, like diabetes and states of insulin resistance. Under conditions in which hepatic glycogen stores are high (i.e. the overnight-fasted state), a decrease in the glycogenolytic rate and an increase in the rate of glucose cycling within the liver seem to be the explanation for the decrease in hepatic glucose output seen in response to hyperglycaemia. During more prolonged fasting, when glycogen concentrations are reduced, a decrease in gluconeogenesis could occur as part of the non-hormonal response to hyperglycaemia [46, 48].

We have found that a diet rich in protein was associated with increased insulin release. Higher fasting glucose production, diminished suppression of hepatic glucose output and enhanced gluconeogenesis all potentially contribute to increased prandial or postabsorptive insulin demand or both on the beta cells.

Acknowledgements. The authors thank the staff of the Clinical Research Unit at Medical Clinic III (S. Rau, M. Mann, and R. Reuter) for invaluable help. We are grateful for the critical discussions with Drs. B. Landau and G. Boden about the design and the analytical methods used in this study.

\section{References}

1. Cohen D, Dodds R, Viberti GC (1987) Effect of protein restriction in insulin-dependent diabetes at risk of nephropathy. BMJ 294: 795-798

2. Dahlqvist G, Blom L, Holmgren G et al. (1985) The epidemiology of diabetes in Swedish children 0-14 years. A six year prospective study. Diabetologia 28: 802-808 
3. Gin H, Aparicio M, Potaux L (1991) Low protein, low phosphorus diet and tissue insulin-sensitivity in insulin-dependent diabetic patients with chronic renal failure. Nephron 57: 411-415

4. Linn T, Ebener K, Raptis G, Laube H, Federlin K (1995) Natural course of insulin sensitivity and insulin reserve in early insulin-dependent diabetes mellitus. Metabolism 44: 617-623

5. Linn T, Geyer R, Prassek S, Laube H (1996) Effect of dietary protein intake on insulin secretion and glucose metabolism in insulin-dependent diabetes mellitus. J Clin Endocrinol Metab 81: 3938-3943

6. Khan MA, Gannon MC, Nuttall FO (1992) The glucose appearance rate following protein ingestion in normal subjects. J Am Coll Nutr 11: 701-706

7. Muller WA, Faloona GR, Unger RH (1976) The influence of antecedent diet upon glucagon and insulin secretion. N Engl J Med 285: 1450-1454

8. Jahoor R, Peters EJ, Wolfe RR (1988) Gluconeogenic precursors supply and glucose production. FASEB $\mathrm{J} 2$ : 1215-1218

9. Landau BR, Wahren J, Chandramouli V, Schumann WC, Ekberg K, Kalhan SC (1996) Contributions of gluconeogenesis to glucose production in the fasted state. J Clin Invest 98: 378-385

10. Radziuk J, pye S, Zhang Z (1993) Substrates and the regulation of hepatic glycogen metabolism. Adv Exp Med Biol 334: 235-252

11. Jungas RL, Halperin ML, Brosnan JT (1992) Quantitative analysis of amino acid oxidation and related gluconeogenesis in humans. Physiol Rev 72: 419-448

12. FAO/WHO/UNU Expert Consultation. (1985) Energy and Protein Requirements. Technical Report Series, No. 724, Geneva. WHO Publications

13. Landau BR, Fernandez CA, Previs SF et al. (1995) A limitation in the use of mass isotopomer distributions to measure gluconeogenesis in fasting humans. Am J Physiol 269: E18-E26

14. Speitling A, Hüppe R, Kohlmeier M et al. (1992) Handbook, Nutrition Survey and Risk Factor Analysis. Wissenschaftlicher Fachverlag Dr. Fleck, Niederkleen

15. VERA Schriftenreihe. Bd. III, Lebensmittel- und Nährstoffaufnahme Erwachsener in der Bundesrepublik Deutschland. Wissenschaftlicher Fachverlag Dr. Fleck (1992), Niederkleen, Germany, chapter 6.4

16. Bingham SA (1994) The use of $24 \mathrm{~h}$ urine samples and energy expenditure to validate dietary assessments. Am J Clin Nutr 59 [Suppl]: 227-231

17. Maroni BJ, Steinman IT, Mitch EW (1985) A method for estimating nitrogen intake of patients with chronic renal failure. Kidney Int 27: 58-65

18. Reinauer H, Gries FA, Hübinger A, Knode O, Severing K, Susanto F (1990) Determination of glucose turnover and glucose oxidation rates in man with stable isotope tracers. J Clin Chem Clin Biochem 28: 505-511

19. Bergman RN, Phillips L, Cobelli C (1979) Physiologic evaluation of factors controlling glucose tolerance in man. J Clin Invest 68: 1456-1467

20. Steele R, Wall JS, De Bodo RC, Altszuler N (1956) Measurement of size and turnover rate of body glucose pool by the isotope dilution method. Am J Physiol 187: 15-24

21. De Bodo RC, Steele R, Altszuler N, Dunn A, Bishop JS (1963) On the hormonal regulation of carbohydrate metabolism: studies with ${ }^{14} \mathrm{C}$ glucose. Recent Progr Horm Res 19: 445-448

22. Gay LJ, Schneiter PH, Schutz Y, Di Vetta V, Jéquier E, Tappy L (1994) A non-invasive assessment of hepatic gly- cogen kinetics and post-absorptive gluconeogenesis in man. Diabetologia 37: 517-523

23. Simpson RG, Benedetti A, Grodsky GM, Karam JH, Forsham PH (1968) Early phase of insulin release. Diabetes 17: 684-692

24. Srikanta S, Ganda OP, Gleason PE, Jackson RA, Soeldner JS, Eisenbarth GS (1985) First degree relatives of patients with Type I diabetes mellitus: islet cell antibodies and abnormal insulin secretion. N Engl J Med 313: 461-464

25. Linn T, Ebener K, Laube H, Federlin K (1996) Simultaneous assessment of A- and B-cell function in newly diagnosed insulin-dependent diabetes mellitus. Endocrinol Metabol 3: 117-123

26. Byrne M, Gliem K, Wank U et al. (1998) Glucagon-like peptide 1 improves the ability of the $\beta$-cell to sense and respond to glucose in subjects with impaired glucose tolerance. Diabetes 47: 1259-1265

27. Flint A, Raben A, Astrup A, Holst JJ (1998) Glucagon-like peptide 1 promotes satiety and suppresses energy intake in humans. J Clin Invest 101: 515-520

28. Linn T, Schneider K, Göke B, Federlin K (1996) Glucagonlike-peptide-1 (7-36) amide improves glucose sensitivity in beta-cells of NOD mice. Acta Diabetol 33: 19-24

29. Otonkoski T, Hayek A (1995) Constitution of a biphasic insulin response to glucose in human fetal pancreatic $\beta$-cells with glucagon-like peptide 1. J Clin Endocrinol Metab 80: 3779-3783

30. Carli F, Webster JD, Halliday D (1997) Growth hormone modulates amino acid oxidation in the surgical patient. Metabolism 46: 23-28

31. Clemmons DR, Smith-Banks A, Underwood LE (1992) Reversal of diet-induced catabolism by infusion of recombinant insulin-like growth factor-I in humans. J Clin Endocrinol Metab 75: 234-238

32. Ketelslegers JM, Maiter D, Maes M, Underwood LE, Thissen JP (1995) Nutritional regulation of insulin-like growth factor-1. Metabolism 44: 50-57

33. Nielsen JH, Molrup A, Montana E, Bonner-Weir S, Weir GC (1994) Transplanted beta cell response to increased metabolic demand: changes in beta cell replication and mass. J Clin Invest 93: 1577-1582

34. Sorenson RL, Brelje TC (1997) Adaptation of islets to pregnancy: $\beta$-cell growth, enhanced insulin secretion and the role of lactogenic hormones. Horm Metabol Res 29: 301-307

35. LeBlanc J, Soucy J, Nadeau A (1996) Early insulin and glucagon responses to different food items. Horm Metab Res 28: 276-279

36. Volpi E, Lucidi P, Cruciani G et al. (1996) Contribution of amino acids and insulin to protein anabolism during meal absorption. Diabetes 45: 1245-1250

37. Taylor R, Magnusson I, Rothman DL et al. (1996) Direct assessment of liver glycogen storage by ${ }^{13} \mathrm{C}$ nuclear magnetic resonance spectroscopy and regulation of glucose homeostasis after a mixed meal in normal subjects. J Clin Invest 97: 126-132

38. Roden M, Perseghin G, Petersen KF et al. (1996) The roles of insulin and glucagon in the regulation of hepatic glycogen synthesis and turnover in humans. J Clin Invest 97: 642-648

39. Nuttall FQ, Gannon MC, Wald JL (1985) Plasma glucose and insulin profiles in normal subjects ingesting diets of varying carbohydrate and protein content. J Am Coll Nutr 4: 437-450

40. Nuttall FQ, Gannon MC (1991) Plasma glucose and insulin response to macronutrients in nondiabetic and NIDDM subjects. Diabetes Care 14: 824-838 
41. Tappy L, Acheson K, Normand S (1992) Effects of infused amino acids on glucose production and utilization in healthy adult subjects. Am J Physiol 262: E826-E833

42. Petersen KF, Laurent D, Rothman DL, Cline GW, Shulman GI (1998) Mechanism by which glucose and insulin inhibit net hepatic glycogenolysis in humans. J Clin Invest 101: 1203-1209

43. Fukagawa NK, Minaker KL, Young VR (1989) Leucine metabolism in aging humans: Effect of insulin and substrate availability. Am J Physiol 256: E288-E294

44. Pisters PWT, Restifo NP, Cerosimo E (1991) The effects of euglycemic hyperinsulinaemia and amino acid infusion on regional and whole body glucose disposal in man. Metabolism 40: 59-61

45. Tessari P, Inchiostro S, Biolo G (1985) Hyperaminoacidemia reduces insulin-mediated glucose disposal in healthy man. Diabetologia 28: 870-872
46. Hetenyi GJ (1982) Correction for the metabolic exchange of ${ }^{14} \mathrm{C}$ for ${ }^{12} \mathrm{C}$ atoms in the pathway of gluconeogenesis in vivo. Fed Proc 41: 104-109

47. Rothman DL, Magnusson I, Katz LD, Shulman RG, Shulman GI (1991) Quantitation of hepatic glycogenolysis and gluconeogenesis in fasting humans with ${ }^{13} \mathrm{C}$ NMR. Science 254: 573-576

48. Moore MC, Connolly CC, Cherrington C (1998) Limitations in estimating gluconeogenesis and Cori cycling from mass isotopomer distributions using [U-13C6]glucose. Eur J Endocrinol 138: 240-248

49. Wajngot A, Chandramouli V, Schumann WC, Efendic S, Landau BR (1991) Quantitation of glycogen/glucose-1-P cycling in liver. Metabolism 40: 877-881 